\title{
Hg Geochemical Character on Soil of Xianling of Ming Dynasty
}

\author{
Guo Li \\ China University of Geosciences \\ Beijing Geological Survey \\ Beijing, China \\ e-mail: guoli_mail@163.com \\ Che Chuxin \\ Beijing Geological Survey \\ Beijing, China \\ e-mail: chenchuxin@163.com
}

\author{
Ding Changshun \\ Beijing Geological Survey \\ Beijing, China \\ e-mail: dingchanghsun@163.com
}

\begin{abstract}
Hg}$,soil gas $\mathrm{Hg}$ and atmospheric $\mathrm{Hg}$ on tomb of Ming Xianling. Xianling is the tomb of the fourth emperor Zhu Gaochi of the Ming Dynasty.Soil samples were collected for determination of mercury. Soil gas $\mathrm{Hg}$ and atmospheric $\mathrm{Hg}$ is analysed on high mercury anomalous areas. The results showed that soil Hg on Treasure Town is close to natural background and on Five Offerings is enriched or anomalous. The content of soil $\mathrm{Hg}$ is enriched in the surface soil layer.Soil gas $\mathrm{Hg}$ is high on $\mathrm{Hg}$ enrichments. Atmospheric $\mathrm{Hg}$ is low on the survey areas. Meteorological conditions influence mercury flux of emission from Soil to atmosphere. Soil gas $\mathrm{Hg}$ is directly affected by the soil Hg.In history, the use of mercury in the mausoleum is a very common phenomenon. Study on the geochemical characteristics of mercury provides the scientific basis for environmental protection and historical research.
\end{abstract}

Keywords-Ming Xianling; soil Hg; soil gas Hg;atmospheric Hg;tomb

\section{INTRODUCTION}

According to the archaeological and historical record, the use of mercury in the mausoleum is a very common phenomenon. Mercury and mercury minerals as anticorrosion material, pigment, drug or the status symbol in and around the tomb becomes a differrent source of mercury from geological bodies[1]. Mercury and cinnabar[2] buried in the soil for a long time.Due to volatile features of mercury[3], gas mercury constantly emitted from soil.Gas mercury was adsorpted by soil in the way up and became anomalous.Using mercury measurement to study the content of soil $\mathrm{Hg}$,soil gas $\mathrm{Hg}[4]$ and atmospheric $\mathrm{Hg}[5]$, the geochemical characteristics of mercury provides the scientific basis for environmental protection[6] and historical research[7].

Lying in Changping District of Beijing,the Ming Tombs are a group of mausoleums for 13 emperors in the Ming Dynasty.It is the extant imperial mausoleum building complex in China that has the largest number of the imperial mausoleums for emperors and empresses.

Xianling is the tomb of Emperor Zhu Gaochi, the fourth ruler of the Ming [8], and his wife Empress Zhang. Emperor Zhu Gaochi was comparatively thrifty in his expenditures, which could be reflected from his smallscaled Xianling Tomb. The tomb covers an area of 42,000 square meters. The main structures, in turn, are Tomb Gate,Gate of Eminent Favor,Hall of Eminent Favor,Gate on the Threshold of Stars,Five Stone Sacrificial Utensils,Soul Tower, and Treasure Town.The Underground Palace is under the Treasure Town.

Soil samples were collected for determination of mercury on Treasure Town, Five Offerings areas and around tomb.

Soil $\mathrm{Hg}$ is analysed by Atomic Fluorescence Spectrometry. A variety of methods of mercury vapor survey[9] were carried out for mercury in air and mercury in soil gas on high mercury anomalous area. Soil gas $\mathrm{Hg}$ and atmospheric $\mathrm{Hg}$ is analysed by the atmosphere of ultra trace mercury analyzer. 


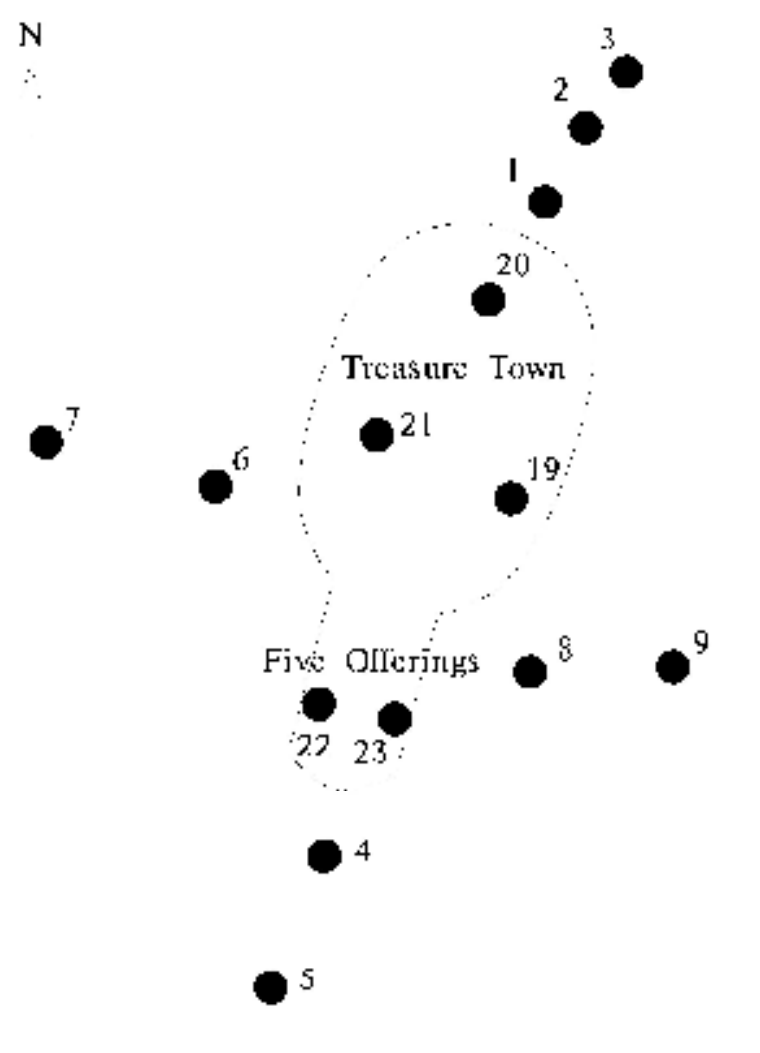

Figure 1. Example of a ONE-COLUMN figure caption.

\section{DisCUSSED PROBLEMS}

\section{A. Characteristics of soil $\mathrm{Hg}$}

Soil samples were collected on Treasure Town.From No.19,20 to 21,Figure 1.which are located in the East,North and West of Precious Top in turn. The content of soil $\mathrm{Hg}$ is $0.347 \mu \mathrm{g} / \mathrm{g}, 0.153 \mu \mathrm{g} / \mathrm{g}$ and $0.151 \mu \mathrm{g} / \mathrm{g}$. They are higher than the soil $\mathrm{Hg}$ background value $0.065 \mu \mathrm{g} / \mathrm{g}$ of China. The Soil $\mathrm{pH}$ value is less than 6.5.

According to environmental quality standard for soil, soil $\mathrm{Hg}$ of No.20 and 21 is closed to the natural background value of soil $0.15 \mu \mathrm{g} / \mathrm{g}$ [10]. Soil Hg of No.19 comes up to the second standard. Soil $\mathrm{Hg}$ is enriched or anomalous in the surface soil on Treasure Town.

Comparison of $0-10 \mathrm{~cm}$ and $10-20 \mathrm{~cm}$ in soil samples found that $\mathrm{Hg}$ is enriched in the surface soil.The content is showed in Table 1. The content of soil $\mathrm{Hg}$ is $0.347 \mu \mathrm{g} / \mathrm{g}$ in the $0-10 \mathrm{~cm}$ and $0.231 \mu \mathrm{g} / \mathrm{g}$ in the $10-20 \mathrm{~cm}$ for No.19. The content of soil $\mathrm{Hg}$ in the $10-20 \mathrm{~cm}$ is higher than the soil $\mathrm{Hg}$ background value of China.The Soil $\mathrm{pH}$ reduces from 6.46 to 5.78 .

The content of soil $\mathrm{Hg}$ is $0.153 \mu \mathrm{g} / \mathrm{g}$ in the $0-10 \mathrm{~cm}$ and $0.077 \mu \mathrm{g} / \mathrm{g}$ in the $10-20 \mathrm{~cm}$ for No.20. Soil $\mathrm{Hg}$ is close to background value of China. The Soil $\mathrm{pH}$ reduces from 5.44 to 5.36. Results indicate that the content of soil $\mathrm{Hg}$ is enriched in the surface soil layer.
High mercury anomalous area was detected on Five Offerings. The results are showed in Table 1 . The content of soil $\mathrm{Hg}$ is $1.845 \mu \mathrm{g} / \mathrm{g}$ for No.22. Soil $\mathrm{pH}$ is 7.22 . Soil samples were collected in the $0-10 \mathrm{~cm}$ layer and soil composed of gravel. The content of soil $\mathrm{Hg}$ is $3.062 \mu \mathrm{g} / \mathrm{g}$ for No.23. Soil pH is 8.10. Soil samples were collected in the $0-20 \mathrm{~cm}$ layer . The composition of soil includes lime, sand and brick.According to environmental quality standard for soil, soil Hg of No.22 and 23 comes up to the third standard.

The composition and properties of soil on Treasure Town are different from Five Offerings areas. Soil pH and soil $\mathrm{Hg}$ are higher on Five Offerings areas.

TABLE I. CONTENT OF SOIL HG AND PH IN TOMB

\begin{tabular}{|l|l|l|l|l|}
\hline \multirow{2}{*}{ No. } & Soil $\mathbf{H g}(\boldsymbol{\mu g} / \mathbf{g})$ & $\boldsymbol{p H}$ & Layers $(\mathrm{cm})$ & \multirow{2}{*}{ Areas } \\
\hline \multirow{2}{*}{19} & 0.347 & 6.46 & $0-10$ & \multirow{2}{*}{ Treasure Town } \\
\cline { 2 - 4 } & 0.231 & 5.78 & $10-20$ & \\
\hline \multirow{2}{*}{20} & 0.153 & 5.44 & $0-10$ & \multirow{2}{*}{ Treasure Town } \\
\cline { 2 - 4 } & 0.077 & 5.36 & $10-20$ & \\
\hline 21 & 0.151 & 6.14 & $0-20$ & Treasure Town \\
\hline 22 & 1.845 & 7.22 & $0-10$ & Five Offerings \\
\hline 23 & 3.062 & 8.10 & $0-20$ & Five Offerings \\
\hline
\end{tabular}

Soil samples were collected to survy mercury enrichments or anomalies around tomb. The results are showed in Table 2. The content of soil Hg is $0.091 \mu \mathrm{g} / \mathrm{g}$ in the North, $0.566 \mu \mathrm{g} / \mathrm{g}$ in the South, $0.327 \mu \mathrm{g} / \mathrm{g}$ in the West,and $0.515 \mu \mathrm{g} / \mathrm{g}$ in the East.

Soil $\mathrm{Hg}$ in the North is close to background value of China. In the peripheral section, the content of soil $\mathrm{Hg}$ is enriched near the tomb and reduces to background value away from tomb.

TABLE II. CONTENT OF SOIL HG AND PH AROUND TOMB

\begin{tabular}{|l|l|l|l|l|}
\hline No. & Soil $\mathbf{H g}(\boldsymbol{\mu g} / \boldsymbol{g})$ & $\boldsymbol{p H}$ & Layers $(\mathrm{cm})$ & Position \\
\hline 1 & 0.091 & 7.79 & $0-40$ & North \\
\hline 2 & 0.083 & 7.61 & $0-40$ & North \\
\hline 3 & 0.071 & 7.66 & $0-40$ & North \\
\hline 4 & 0.566 & 8.54 & $0-40$ & South \\
\hline 5 & 0.258 & 8.66 & $0-40$ & South \\
\hline 6 & 0.327 & 8.40 & $0-40$ & West \\
\hline 7 & 0.250 & 8.30 & $0-40$ & West \\
\hline 8 & 0.515 & 8.23 & $0-40$ & East \\
\hline 9 & 0.025 & 7.92 & $0-40$ & East \\
\hline
\end{tabular}

\section{B. Features of soil gas $\mathrm{Hg}$ and atmospheric $\mathrm{Hg}$}

We measured soil gas $\mathrm{Hg}$ and atmospheric $\mathrm{Hg}$ on high mercury anomalous area of Five Offerings. The results are showed in Table 3 and Table 4.

The monitoring parameters of No.22 are time from $15: 40$ to $16: 40$, average temperature $31.1^{\circ} \mathrm{C}$, average soil temperature $36.9^{\circ} \mathrm{C}$. Soil gas $\mathrm{Hg}$ decreased from 57.383 $\mathrm{ng} / \mathrm{m}^{3}$ to $43.590 \mathrm{ng} / \mathrm{m}^{3}$. Hg concentration in atmosphere declined from $9.453 \mathrm{ng} / \mathrm{m}^{3}$ to $4.538 \mathrm{ng} / \mathrm{m}^{3}$. Then the data did not obviously change any more. 
The monitoring parameters of No.23 are time from 17: 00 to 18: 00 , average temperature $29.1^{\circ} \mathrm{C}$, soil temperature from $28.3^{\circ} \mathrm{C}$ to $24.6^{\circ} \mathrm{C}$. Soil gas $\mathrm{Hg}$ decreased from 6.430 $\mathrm{ng} / \mathrm{m}^{3}$ to $5.632 \mathrm{ng} / \mathrm{m}^{3}$. Atmospheric $\mathrm{Hg}$ decreased from $4.352 \mathrm{ng} / \mathrm{m}^{3}$ to $3.362 \mathrm{ng} / \mathrm{m}^{3}$. Then the data held the line.

Soil gas $\mathrm{Hg}$ is large different on the monitoring points of high mercury anomalous area. The content changed from $57.383 \mathrm{ng} / \mathrm{m}^{3}$ to $5.632 \mathrm{ng} / \mathrm{m}^{3}$. Atmospheric mercury distributes evenly in the air. The highest content of soil gas $\mathrm{Hg}$ is 10 times of atmospheric $\mathrm{Hg}$. The data of soil gas $\mathrm{Hg}$ are far lower than the average content $559.65 \mathrm{ng} / \mathrm{m}^{3}$ of Beijing urban[11]. Hg concentration in atmosphere is same as the average content $3.13 \mathrm{ng} / \mathrm{m}^{3}$ of Beijing urban[11].

A good linear relationship for soil gas $\mathrm{Hg}$ versus atmospheric $\mathrm{Hg}$ was confirmed, which indicated that the sources of soil gas $\mathrm{Hg}$ may be the more significant contributors of mercury to the atmosphere than previously realized[11].

Although meteorological conditions[12] influence mercury flux of emission from Soil to atmosphere, Soil gas $\mathrm{Hg}$ is directly affected by the soil $\mathrm{Hg}$.

At the same monitoring spot, air temperature is maintained constant. During the monitoring period, temperature changed from $31.1^{\circ} \mathrm{C}$ to $29.1^{\circ} \mathrm{C}$ and soil temperature sharp declined from $37.7^{\circ} \mathrm{C}$ to $24.6^{\circ} \mathrm{C}$. The total radiation intensity reduced from $467.1 \mathrm{~W} / \mathrm{m}^{2}$ at $15: 40$ to $8.8 \mathrm{~W} / \mathrm{m}^{2}$ at $18: 00$. In the monitoring period, soil moisture,relative humidity and windspeed kept stable.The result is showed in Table5.Soil temperature is one of the important factors affecting the result of soil gas mercurometric survey.

TABLE III. CONTENT OF SOIL GAS HG IN DIFFERERNT MONITORING PARAMETERS

\begin{tabular}{|c|l|l|l|l|}
\hline \multirow{2}{*}{ No. } & \multicolumn{1}{|c|}{$\begin{array}{c}\text { Atmospheric } \\
\mathbf{H g}\left(\mathbf{n g} / \mathrm{m}^{3}\right)\end{array}$} & Time & Soil temp. $\left({ }^{\circ} \mathrm{C}\right)$ & \multicolumn{1}{|c|}{ Temp. $\left({ }^{\circ} \mathrm{C}\right)$} \\
\hline \multirow{3}{*}{22} & 9.453 & $15: 40: 00$ & 33.2 & 31.3 \\
\cline { 2 - 5 } & 7.507 & $16: 00: 00$ & 37.4 & 31.3 \\
\cline { 2 - 5 } & 6.510 & $16: 20: 00$ & 37.7 & 30.8 \\
\cline { 2 - 5 } & 4.538 & $16: 40: 00$ & 37.6 & 30.9 \\
\hline \multirow{3}{*}{23} & 4.352 & $17: 00: 00$ & 28.3 & 30.7 \\
\cline { 2 - 5 } & 3.681 & $17: 20: 00$ & 25.9 & 29.6 \\
\cline { 2 - 5 } & 3.372 & $17: 40: 00$ & 24.9 & 28.5 \\
\cline { 2 - 5 } & 3.362 & $18: 00: 00$ & 24.6 & 27.9 \\
\hline
\end{tabular}

TABLE IV. CONTENT OF ATMOSPHERIC HG IN DIFFERERNT MONITORING PARAMETERS

\begin{tabular}{|c|l|l|l|l|}
\hline \multirow{3}{*}{ No. } & \multicolumn{1}{|c|}{$\begin{array}{c}\text { Soil Gas Hg } \\
\mathbf{n g} / \mathbf{m}^{3}\end{array}$} & Time & Soil temp. $\left({ }^{\circ} \mathrm{C}\right)$ & \multirow{2}{*}{ Temp. $\left({ }^{\circ} \mathrm{C}\right)$} \\
\hline \multirow{3}{*}{22} & 57.383 & $15: 50: 00$ & 37.4 & 31.8 \\
\cline { 2 - 6 } & 48.727 & $16: 10: 00$ & 37.3 & 31.1 \\
\cline { 2 - 6 } & 43.590 & $16: 30: 00$ & 37.8 & 31.0 \\
\hline \multirow{3}{*}{23} & 6.430 & $17: 10: 00$ & 26.8 & 30.0 \\
\cline { 2 - 6 } & 6.103 & $17: 30: 00$ & 25.3 & 29.0 \\
\cline { 2 - 6 } & 5.632 & $17: 50: 00$ & 24.7 & 28.1 \\
\hline
\end{tabular}

TABLE V. TOTAL RADIATION INTENSITY AND TEMPERATURE

\begin{tabular}{|c|c|c|c|c|}
\hline Time & $\begin{array}{l}\text { Total Radiation } \\
\text { Intensity }\left(\mathrm{W} / \mathrm{m}^{2}\right)\end{array}$ & $\begin{array}{c}\text { Soil Moisture } \\
(\%)\end{array}$ & $\begin{array}{c}\text { Relative } \\
\text { Humidity (\%) }\end{array}$ & $\begin{array}{c}\text { Windspeed } \\
(\mathrm{m} / \mathrm{s})\end{array}$ \\
\hline $15: 40$ & 465.3 & 5.07 & 39.3 & 0.8 \\
\hline $15: 50$ & 467.1 & 5.72 & 38.2 & 0.8 \\
\hline 16:00 & 445.8 & 5.76 & 38.3 & 1.0 \\
\hline $16: 10$ & 437 & 5.76 & 39.5 & 0.7 \\
\hline $16: 20$ & 422.6 & 5.77 & 40.6 & 0.7 \\
\hline $16: 30$ & 389.2 & 5.77 & 40.1 & 0.6 \\
\hline $16: 40$ & 360.3 & 5.78 & 39.5 & 0.6 \\
\hline 17:00 & 142.8 & 7.92 & 38 & 0.7 \\
\hline $17: 10$ & 193.1 & 7.89 & 40.4 & 0.6 \\
\hline $17: 20$ & 75.3 & 7.86 & 42.6 & 0.6 \\
\hline $17: 30$ & 25.4 & 7.84 & 43.2 & 0.6 \\
\hline $17: 40$ & 13.9 & 7.81 & 44.3 & 0.5 \\
\hline 17:50 & 11 & 7.81 & 46.3 & 0.4 \\
\hline 18:00 & 8.8 & 7.81 & 47.2 & 0.3 \\
\hline
\end{tabular}

\section{CONCLUSIONS}

Mercury enrichments or anomalies in soils are a general phenomenon in Chinese, and investigation on source, transport cycle and fate of $\mathrm{Hg}$ in soil is essential for evaluating environmental. The mercurometric survey was employed to detect or judge the mercury character of tomb.Mercury vapor measurement has yielded preliminary results in the detection of mercury source.

There are mercury enrichments or anomalies in soils of Xianling tomb. The average content of soil $\mathrm{Hg}$ is closed to the natural background on Treasure Town. Soil Hg on Five Offerings is anomalous. The content of soil $\mathrm{Hg}$ comes up to the third standard.

Soil gas $\mathrm{Hg}$ is high on areas of anomalous soil $\mathrm{Hg}$ and is far lower than the average content of Beijing urban。 The sources of soil $\mathrm{Hg}$ may be the more significant contributors of mercury to the soil gas. $\mathrm{Hg}$ concentration in atmosphere is same as the average content of Beijing urban.

Meteorological conditions influence mercury flux of emission from Soil to atmosphere. Soil temperature is one of the important factors affecting the result of soil gas mercurometric survey.

\section{ACKNOWLEDGMENT}

This study was supported by Beijing Ming Tombs Office of the Special Administrative Region.

\section{REFERENCES}

[1] L.Chongmin,S.Cangyi,H.Shuqi,and Y.Weidong, "Mercurometric survey and $\alpha$-cup radon measurement in archeological detection of the Qin Shi Hang tomb," Geophysical and Geochemical Exploration, vol. 29,Aug.2005,pp.336-341,doi:10.3969/j.issn.10008918.2005.04.015.

[2] Z. Lixin,M. Shengming, and W. Zhifend, "New advances in the study of urban environment geochemistry," Geophysical and 
Geochemical

Exploration

vol.28,Apr.2004.pp.9598,doi:10.3969/j.issn.1000-8918.2004.02.001.

[3] D. Qianjin,F. Xinbin, and T. Guiping, "The geochemical behavior of mercury in soil and its pollution control," Geologygeochemistry,vol.30,2002,pp.75-79,doi:10.3969/j.issn.16729250.2002.04.013

[4] Z. Xiaocheng,D. Jianguo,and W. Chuanyuan, "Geochemical characteristics of radon and mercury in soil gas in Lhasa,Tibet,China,"Environmental Science, vol.28, Mar. 2007, pp.660-663, doi:10.3321/j.issn.0250-3301.2007.03.038.

[5] W. Shaofeng,F. Xinbin, and Q. Guangle, "Progress in research on natural sources of atmospheric $\mathrm{Hg}$," Earth and Environment, vol.34,2006,pp.1-11,doi:10.3969/j.issn.1672-9250.2006.02.001.

[6] H. Yuehong, "Review of Mercury pollution Distribution status research at home and aborad," Environmental Protection Science,vol.34,Feb.2008,pp.38-41,doi:10.3969/j.issn.10046216.2008.01.012.

[7] X. Xuejin,C. Yong,and C. Zhizhong, "Mercury in Qin Mausoleum: Whether there existed mercury and whence the mercury," Geological Bulletin of China,vol.32,Oct.2013,pp. 1485-1492, doi:10.3969/j.issn.1671-2552.2013.10.001.
[8] L. Yi, "Study on the Structure of the Emperors Mausoleums of Ming Dynasty," Northern Cultural Relics , vol.72, 2002,pp.3847,doi:10.3969/j.issn.1001-0483.2002.04.008.

[9] L. Huazhong, Y. Fan, and Z. Xuejun, "The application of mercury vapor survey to archaeological detection of the Spring-Autumn tomb in Hancheng city," Geophysical and Geochemical Exploration,vol.4,Aug.2013,pp.670-674,doi:10.11720/j.issn.10008918.2013.4.7.

[10] China National Environmental Protection Agent. GB 15618-1995 Environmental quality standard for soil. Beijing: China Environmental Science Press, 1995(in Chinese).

[11] C. Hangxin, Z. Guangming \& Z. Cuangdong, "Regional ecogeochemical assessment of mercury in soils in Beijing," Earth Science Frontiers, vol. 15, Sep. 2008,pp. 126-145, doi: 10.3321/j.issn:1005-2321.2008.5.0114.

[12] Z. Changyi,S. Changyi,and Z. Jinhua, "The influences of small amounts of precipitaion on soil gas mercurometric survey," Geophysical and Geochemical Exploration,vol.24, Dec. 2000,pp. 452-454, doi:10.3969/j.issn.1000-8918.2000.06.008. 